\title{
Vinchel Contemplates Market Expansion Strategies
}

Richard Hise, (Email: rhise@mays.tamu.edu), Texas A\&M University

David Barcan, St. Petersburg State University, Russia

\begin{abstract}
This case is prepared as a basis for class discussion rather than to illustrate either effective or ineffective handling of a business situation. Support for this case was provided by the U.S. Agency for International Development (USAID) through the Eurasia Foundation in Washington, D.C. for which we are very grateful. We would like to express our gratitude to the management of Vinchel Winery for their participation in discussions and provision of materials without which this case study would not have been possible.
\end{abstract}

\section{INTRODUCTION}

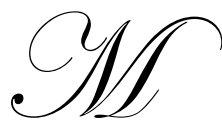

r. Anatoly I. Bondarev, General Director of the Chelyabinsk Winery (Vinchel), looked forward to an ordinary day: A planning session, meetings with managers, several business trips to downtown. But an argument that erupted during the afternoon planning session was unsettling and caused him to rethink his general strategies for expanding the business from essentially a regional operation in Russia to one involving all of Russia.

The planning session started pleasantly enough. The top managers exchanged ideas as to how sales could be increased in Chelyabinsk, the oblast with the same name as the city, and the other oblasts in the region. The Marketing and Sales Director reported on the current sales figures; on the whole, they were considered to be satisfactory and in harmony with the opportunities existing. They discussed briefly how effective the city dealers were and how retail sales were going. Next, they discussed how their Ural partners might assist in achieving the desired sales increases, particularly in Sverdlovsk, by identifying appropriate marketing and sales strategies.

As the discussion was calmly ending, the floor was taken by one of the company's distributor partners who happened to be in Chelyabinsk and was asked by Mr. Bondarev, as a courtesy, if he had anything to say. His comments greatly surprised Mr. Bondarev and Vinchel's other officers.

The partner stated openly that the company's present sales in the various regions only appeared to be satisfactory-- an opinion that he said was shared by the other partners.

Sales were being hurt by relatively cheap imported wines and competitors located in the European part of Russia. These companies emphasized the development of rapid and intensive distribution networks, had developed a formal system of selecting and evaluating distributors, and effectively collaborated with them, chiefly through flexible and favorable credit terms. The partner finished his speech by saying, "No offense, but you don't realize the abyss that will occur if the winery does not change considerably its system of working with partners, does not start a partner relationship and development program, and provide organizational, financial, training, and other assistance. Of course, we, your old partners, will work with Vinchel as long as we can, but if these are not implemented, the major part of the present Vinchel partners will turn to its competitors."

These comments woke up those attending the meeting. The Financial Director tried to persuade the others that the picture was not as bad as that painted by the partner. He was joined by the Planning Department Head and 
the Supplies Director. The Marketing and Sales Director, on the other hand, sided with the partner, stating that developments in the market and the behavior of a number of very important clients supported the partner's views.

In contemplating the foregoing discussion, Mr. Bondarev realized that the worst that Vinchel could do was to maintain the status quo. Giving support to his conclusion was the experience of the Massandra Winery.

Massandra was owned by the Ukrainian State Committee of Horticulture and Wine Industry (Goscomsadvinprom); it was the most well-known and prestigious wine producing company in the territory of the former Soviet Union. With its more than 100- year history, "Massandra produced the finest muscats in the former Soviet republics, as well as the well-known brands of the dessert wines, such as "Tokai," "Pinot-gris," "Ceaucour," and others. The company was featured in the Guinness Book of Records as having the most famous collection of distinguished wines. According to different valuations, its value fluctuated between 350 million to one billion dollars. The company participated more than once in the famed Sotheby's auction, earning hundreds of thousands of dollars. In short, one could hardly imagine a more eminent wine producing company in the territory of the former Soviet Union.

Nevertheless, in the first part of the 1990s, Massandra lost most of its markets abroad and significantly ceded its traditional markets in the CIS. Although the market for Massandra wines was developed rather rapidly in Russia from 1994 to 1998, it was clear the company was taking advantage of the overall upsurge in the market and not making viable promotion and distribution efforts. It was the August crisis of 1998 that tested the quality level of Massandra's sales system since the devaluation of the ruble affected the Ukrainian producers, including Massandra, relatively little. In the course of nine months in 1998, Massandra sold 180 thousand decaliters compared to one million in 1996. Since 1996, the company's sales decreased five consecutive years in the Ukraine. By not being concerned with distribution or advertising, instead counting on the reputation of the brand and the company itself and its seemingly stable position in traditional markets, Massandra ended up being replaced by the Moldavian and Georgian wine-makers in the Russian and even the Ukrainian markets.

\section{THE WINE INDUSTRY}

The winemaking process is captured in Exhibit 1.

\section{Economics}

Investing in a new vineyard involves land purchases, preparation, irrigation (if required), trellises, and the necessary machinery, such as, tractors, sprayers, pruners, and harvesters (which can be either purchased or leased).

In operating a winery, the bulk of the investment outlay goes for land, buildings and cooperage, that is, the large stainless steel tanks and a variety of smaller wooden casks used for aging. Other equipment--destemer/crusher, fermenting/draining tanks, presses, centrifuges/filters, refrigerator units, bottling lines, pumps and pipe works--is expensive, but some of the processes, like crushing and bottling, may be sub-contracted.

The major cost in operating a vineyard is the outlay for labor. Additional savings in this area are believed possible. A full mechanization will reduce pruning costs by one-half and picking by two-thirds. Fertilizers, pesticides and herbicides add to operating costs. Aging in bottles can be costly, but some growers do so for only part of their production, then selling it later at higher prices.

The costs of exporting wines are substantial, involving all kinds of expenditures-- for transportation, brokerage, breakage, insurance, and import duties. R\&D expenditures will be a significant cost as companies continually seek better varieties at lower costs. By increasing levels of production, significant cost reductions can be achieved. In the late 1970s, for example, it was estimated that a northern coastal California winery would incur a $\$ 24$ per case cost at an output of 10,000 cases. At 175,000 cases, the cost would drop to $\$ 6$. It would be $\$ 2$ and $\$ 1$, respectively, for 1.25 million cases and five million cases. ${ }^{1}$ 
Growing grapes is a long-run venture. A 10-year break-even period is projected for a new vineyard or replanting of an old one. Uncertainties can be a real problem. One of these is weather. An early spring rain in 1996 caused a small grape crop for Robert Mondavi Winery, resulting in lower sales for its biggest seller, Woodbridge Chardonay. El Niño reduced California output by 13\% in 1998 from 1997's record volume.

Disease can be catastrophic. In 1992, Robert Mondavi Winery had to rip out and replant 600 acres because of phylloxera infestation. ${ }^{2}$ The recent shortage of financing availability has been a concern, brought on chiefly by several large banks exiting from lending to wineries.

Some purchasers of wine are not truly consumers but are, instead, investors. In May 1997, 18,000 bottles from Andrew Lloyd Webber's wine cellar fetched \$6 million at auction, double the high-end, pre-sale estimate. Three cases of Chateau Latour a' Pomeral sold for $\$ 57,730$ each. ${ }^{3}$ Christie's auctioned a 1,500 case collection from a single private cellar in Great Britain. Total sales were \$1.5 million and included such vintages as 1945 La Mission Haut-Brion, 1947 Cheval Blanc, 1959 Mouton-Rothschild, 1982 Cheval Blanc, 1961 Hermitage la Chapelle, 1978 Hermitage la Chapelle, and 1976 Cuvee Anne Schlumberger Gewurtzraminer. ${ }^{4}$

\section{Products}

There are a large number of different kinds of wines. Varieties differ according to the type of grape used and the flavorings that are added. Flavorings are usually derived from the type of barrel (usually oak) that is used to store the wine.

White wines are typically made from light-colored grapes and tend to be lighter in taste than blush or red wines. Red wines are typically produced from darker-colored grapes and often their stems are included in the production process.

In traditional markets, wine is mainly consumed with meals centered around red meat; those markets are the major consumers of red wines. Strong red wines are slowlyfalling out of favor as their strength is no longer considered desirable. While white wines are often drunk with fish and other white meat dishes, they are also consumed on their own and are the driving force in new-market expansion. Rosés are doing quite well. Their lighter color often seduces drinkers into thinking they have less strength and calories than the reds; rosés frequently serve as a white drinker's transition to red wines. ${ }^{5}$

Wines contain a number of dimensions. These include color; alcoholic strength; varietal character and winemaking style, including fizzyness, balance of odors and balance of flavors; and its container size, shape, color, and material. ${ }^{6}$

\section{VINCHEL WINERY}

Vinchel Winery was established in 1969. In 1976, it was united with the Kopeisk Winery, which is located in a suburb of Chelyabinsk. In 1993, it became a joint stock venture. Currently, Vinchel is a closed stock venture, with all of the stock belonging to the administrators and employees.

The city of Chelyabinsk, with a population of 1.2 million, is located on the Miass River, 1,500 kilometers east of Moscow in the southeastern part of the Ural Mountains and foothills. One-third of the regions is farmland, and it is rich in such minerals as brown coal, copper, zinc, and gold.

The city is a center of heavy industry, with iron and steel plants, a steel-pipe plant, a zinc refinery, and factories manufacturing machine tools and dies, road-building equipment, and precision instruments. The city is located on Russia's main east-west railroad. It is the center of Russia's atomic energy research program. 
In the late 1980s, the winery underwent a major renovation. Equipment was added from the Czech Republic, as were production lines from the Ukraine. In 2000, 450 persons were employed by the company; 100 were sales personnel.

The factory is situated in the center of Chelyabinsk. It contains four major areas: preparation, bottling, warehousing, and transportation. During the Soviet period, total capacity was 300,000 decaliters per month; in 2000, it was 45,000 decaliters per month, with the Chelyabinsk facility accounting for two-thirds of the output and Kopeisk one-third. The warehouse is capable of holding 700,000 decaliters of wine materials. All of these come from Uzbekistan, Moldova, Ukraine, or southern Russia. The company has secured 20 patents for its winemaking inventions.

Vinchel provides much of its own transportation through three types of trucks: two Kamaz trucks (seventon) capacity, three gazel trucks (one and one-half ton capacity), and five half-ton capacity trucks. When especially large loads are needed, the company rents trailers and uses rail transportation. All shipments in the Chelyabinsk region and in the Urals go by truck.

Vinchel produces mainly fortified and half-sweet wines. There are more than 30 brand names falling into three major groups:

- $\quad$ Staraya Taverna Wines (12\% of sales)

- $\quad$ Kladovaya Bondarya Wines (18\% of sales)

- $\quad$ Arabella Wines (the most fortified) (20\% of sales)

Each of these major groups includes about $10 \%-15 \%$ of the company's brands. Forty percent of the company's brands account for $60 \%$ of its turnover. Vinchel wines are bottled in the "European" bottle, which is produced in Russia. Labels are made in Finland.

About half of the company's products are sold in the Chelyabinsk oblast. Thirty-five percent are sold in the Urals region, $15 \%$ from the Urals to the Volga area, with small amounts of sales in the Central Asian republics and Siberia. Vinchel does not export any of its products.

Vinchel has 50 partner distributors working in the Urals. Twenty others serve the other markets. The Ural distributors are extended credit with payment expected in 10-30 days. The others are required to make preliminary payments. Factory bases and shops are located in the Chelyabinsk region. All of their employees are considered to be Vinchel personnel.

Vinchel's wines are targeted for the lower-middle and middle-middle classes. Less prosperous individuals tend to purchase less strong and cheaper wines.

The advertising budget is $0.5 \%$ of the company's turnover. Eighty percent of advertising is product oriented; $20 \%$ is designed to promote the company's image and reputation. Leaflets, flyers and small brochures are the preferred promotional tools.

In 1998-1999, Vinchel entered its products in a number of international exhibitions. In all, Vinchel brands were awarded a total of 45 medals--14 gold, 13 silver, and 13 bronze (Exhibit 2).

Vinchel's turnover figures for 1995-2000 were: 


\begin{tabular}{ll} 
Year & Rubles* \\
\hline 1995 & 200 billion \\
1996 & 201 billion \\
1997 & 221 billion \\
1998 & 299 million \\
1999 & 326 million \\
2000 & 342 million \\
\hline
\end{tabular}

Profit before taxation has averaged about $15 \%$ to $20 \%$ per year.

The company's balance sheet as of September 30, 2000 is found in Exhibit 3.

* Until 1997, turnover figures were expressed in billions of rubles. In 1998, the new ruble made the figures smaller by three digits. (After 1997, 1,000 old rubles equals one new ruble).

\section{THE RUSSIAN ECONOMY}

In late 1991, the Soviet Union ended three quarters of a century of Communist rule. Under Communism, the Russian economy was managed by the government; central planners determined what goods would be produced and what their quantities and quality would be. These central planners selected suppliers and distributors and decided which markets were open for industry. There were around 200,000 state-owned enterprises, with 600 accounting for $47 \%$ of the total output of the Soviet Union. Most of these enterprises enjoyed monopoly positions. Soviet citizens did not have private property rights.

The dissolution of Communism moved the Russian economy into one that was driven by markets instead of central planners. But a whole host of underpinnings, part and parcel of a free enterprise system, would be required. These included prices and production being determined by markets; binding, enforceable private contracts; individual ownership rights in land; private mortgage lending; a commercial banking structure; unfettered individual investment in for-profit enterprises; and taxes light enough to encourage savings, investment and risk taking. And a mechanism would have to be established for the privatization of the state-owned industries.

Achieving this infrastructure was deemed to be more difficult in Russia than it would be in the former eastern-bloc countries, like Poland, which have had a freemarket economy before being taken over by the Soviet Union in 1945. Nina Khrushchev, granddaughter of Soviet dictator, Nikita Khrushchev, perhaps said it best: "There could not have been a culture more out of touch with Adam Smith." Echoed acting prime minister Yegor Gaidar: "After seven decades of a regime for which private enterprise was not merely a dirty word but a criminal act...the hostility toward private property permeated all of the Soviet legislation and law enforcement." 7

On the other hand, Russia has a number of pluses including a highly literate citizenry; skilled work force, especially in the sciences and engineering; immense natural resources, including oil, natural gas, timber, aluminum and diamonds; 6.5 million square acres of land stretching over 11 time zones; and a younger generation that is highly supportive of democracy and free enterprise.

Foreign governments and international organizations poured vast amounts of money into post-communist Russia. The United States, through the Export-Import Bank, OPIC, the U.S. Department of Agriculture, IMF, and World Bank, provided $\$ 20$ billion of assistance. For a variety of reasons, these funds did little good. They often fell into the hands of crooked politicians or organized crime syndicates. The remaining funds were used to prop up inefficient companies, often banks, which should have been allowed to fail. Shares of privatized companies were often concentrated in the hands of insiders who then sold them at a huge profit and moved the proceeds off shore. Many workers did not understand the concept of corporate ownership and, thus, sold their shares at a fraction of their value.

On August 17, 1998 the Russian government announced that it was incapable of making payments on $\$ 40$ billion of corporate and bank debt to foreign creditors. At the same time, the ruble was devalued. The Russian economy collapsed. Inflation was rampant. Dozens of banks became insolvent. Savings accounts were frozen. Russians who kept money at home saw the value drop significantly. Senior citizens lost pensions. Unemployment 
skyrocketed to almost eight percent by the end of the year. The average wage for those lucky enough to have a job dropped from $\$ 160$ to $\$ 55$ a month.

The nation's gross national product, which was $\$ 422$ billion in 1997, dropped to $\$ 132$ billion in 1998 . The Russian stock market lost $90 \%$ of its value. Foreign investment, which reached $\$ 4$ billion in 1997, plummeted to $\$ 1.7$ billion in 1998 . The prices of imports rose dramatically, as did those of Russian goods using foreign components. Stocks of essential foodstuffs dwindled. Millions were unable to pay for health care; those that could faced severe medicine shortages. ${ }^{8}$

Conditions improved somewhat, fueled mainly by increases in the price of oil and the ruble devaluation. Wage and pension arrears declined significantly and the budget is balanced. Some foreign investors took a more positive outlook. ${ }^{9}$ The economy expanded by $3.2 \%$ in 1999 and was expected to increase by $5.5 \%$ in 2000 . A sizable middle class emerged. With monthly incomes between $\$ 800$ to $\$ 7,000$ a month, these 12 million to 30 million people represent $8 \%$ to $20 \%$ of Russia's 145 million people. $^{10}$

The Economist projected that growth in the Russian economy would slow to 4.0\% in 2001. Total GDP for 2001 was estimated to be $\$ 252.6$ billion, or $\$ 1,740$ per capita. Inflation was pegged at $18.0 \%{ }^{11}$

\section{FURTHER EXPANSION IN RUSSIA}

The General Director and other executives believed that it would be impossible to expand all at once into the areas of Russia that were currently not receiving Vinchel's products. Therefore, they reasoned, they needed to develop a scheme prioritizing the expansion effort. Once it was decided which new areas to target, they would have to grapple with developing appropriate selling, distribution and pricing strategies. In all cases, it was felt to be important that the competitive environment facing Vinchel be considered.

\section{The Russian Wine Market}

Under the Soviet regime, Russia was one of the world's largest wine producers, consumer and importer. However, during the mid-1980s, the government went on a crusade to cut into citizens' consumption of alcoholic beverages. The effort was a success as alcohol consumption fell 50\% in only six years. Much of this decline was effected by reducing the size of Soviet vineyards by $23 \%$, from 1.3 million hectares to one million. Total production was 1.8 billion liters in 1992, and was projected to increase to 3.4 billion by 2000 .

The former Soviet Union exported only one percent of its output. Moldova and Georgia led the exporting effort. Some activity from Russia and Ukraine with their sparkling wines took place. A portion of Moldova's and Georgia's production was sent to Russia to be used as blends in its domestic production. ${ }^{12}$

It was estimated that Russians consumed, exclusive of sparkling wines, 478 million liters of wine in 1997, for a per capita value of $\$ 23.57$ and a per capita volume of 21.1 liters. By 2012, these were projected to be, respectively, 659, $\$ 62.78$ and 25.4 . The respective percentage increases are $38 \%, 167 \%$ and $21 \% .{ }^{13}$

In Russia, wine consumption is evenly split between red and white wines, a plus for Vinchel as most of its production is red wine. In summer, more white wine is consumed than red, whereas in winter, the opposite occurs. Also, a plus for Vinchel is the Russian preference for fortified and dessert wines; Russian wine consumers prefer "something sweet."

\section{Prioritization}

Since 1992, Vinchel had several times developed methods for prioritizing expansion into the southern Urals. These relied heavily on their executives' experience in this area and a minimum level of statistical data. 
However, there was unanimous agreement that a more rigorous approach was needed as a full-scale expansion into the rest of Russia was plotted.

With the help of his staff, Mr. Bondarev concluded that a region's population, its purchasing power, the turnover of wine, and the distance of its major city from Chelyabinsk would be major factors in determining the area's suitability as a market for Vinchel's wines.

Some of the less quantitatively-oriented members of Marketing Services requested that qualitative measures should also be included in the model, particularly wine preferences of the population, cultural peculiarities, tradition, and social structure. They also agreed that the priority expansion model should recognize that sales of expensive and cheap wines varied greatly from region to region even when purchasing power was similar.

Exhibit 4 contains Vinchel's evaluation of 76 regions in Russia, taking into account the various factors used. (Exhibit 5 contains a map of Russia.) The Consumer Index is comprised mainly of a region's purchasing power and the turnover of wine products in that region. The data in Exhibit 4 were developed from information available in 1996-1997 -- before the August 1998 economic and financial meltdown. However, Mr. Bondarev was comfortable with these statistics because a spot check in 2000 revealed that the 1996-1997 data accurately portrayed the current situation and suggested that little or no change would occur in the future.

Based on the data contained in Exhibit 4, the company's marketing and sales personnel planned to divide the 76 regions into three groups: Regions of Major Sales (RMS), Regions of Experimental Sales (RES), and Regions of Representative Sales (RRS). For each group, the Director General set significantly different sales and marketing agendas: maximization of bulk sales in relation to cost for RMS; using sales in RES to gain a better understanding of wine consumption, product assortment and pricing policies; and consolidating Vinchel's prestige through appropriate product assortments in RRS, even if "reasonable" losses occurred.

After analyzing the data in Exhibit 4, the Director General decided that no more than 20-25 of the regions were appropriate for expansion.

\section{Selling Strategies}

Currently, the sales department consisted of a department head and five sales agents. Two were responsible for sales within the city of Chelyabinsk and the oblast, two handled regional sales, and one was completely occupied with paper work. It was obvious that this current structure was inadequate to accomplish the expansion objectives, but the Director General and head of the sales department differed sharply over what needed to be done and the marketing department had its own ideas.

The head of the sales department suggested assigning three sales persons to three groups of regions and extending their authority and freedom of action regarding financial matters. The two people presently taking care of sales in Chelyabinsk and the oblast would continue in this capacity, as would the person doing the paper work. Thus, the sales head felt that the only requirement was one additional sales person. On the other hand, the Director General was confident that this "cosmetic" change would hardly accomplish the expansion effort that was being considered.

The marketing department agreed with the head of sales and argued that it was necessary to create a special category of territorial trade representatives for those regions in which an intensive strategy was contemplated. Both the head of sales and the various marketing personnel pushed for extending the idea of territorial trade representatives into the experimental sales and representative sales regions were they would work directly with distributors.

However, the Marketing and Sales Director supported a more radical structure. He pushed for a matrix approach in which territorial trade representatives and regional managers would intersect with several brand managers since promotion of the major product lines of Vinchel required different marketing strategies. Moreover, the Marketing and Sales Director felt that the brand managers would benefit from this type of organization because 
their interaction with the territorial trade representatives and regional managers would keep them "closer to the market".

\section{Distribution Strategies}

Vinchel had, for the most part, adhered to a strategy of intensive sales which was justified for its lowerpriced products sold to customers with limited incomes. The downside of this strategy was dealing with numerous middlemen, payment delays and the enormous amount of documentation and paper work required. Two major upsides resulted. Vinchel's products were available for consumers in a wide number of outlets and the company maintained good control over its prices because middlemen were not interested in inflating prices on Vinchel's lower-priced products. Vinchel had never used a selective distribution strategy and had no clear idea of its benefits and how to implement it.

The company also had limited experience working with large distributors. The Director General did not feel that a potential problem for the non-use of large distributors -- being "cut off" from retailers -- would adversely affect Vinchel's sales. Also, Vinchel would not have to offer large discounts and liberal credit terms to the numerous smaller vendors, although they caused a lot of work for the logistics department.

Mr. Bondarev felt that it was necessary to hammer out a policy for managing accounts receivable. He estimated that Vinchel could sell about one-third of its present product on a cash and prompt payment basis, another third by extending credit for 20 days and the last third on credit terms until the end of the month plus 10 days. But, he maintained that these rules of thumb would have to be modified according to whether "elite" or "standard" wines were being sold.

Another area of concern was the type of support Vinchel would have to provide middlemen. Mr. Bondarev felt that this depended on the volume of sales, the level of investment required, the degree of supervision needed, and the middlemen's tolerance for risk. He fired off a memo to the Marketing and Sales Department, telling them to give him their ideas in four major areas of support for middlemen: marketing, business services, indirect financial support, and direct financial support. His memo attached particular importance to the systematic training of middlemen.

Vinchel's chief engineer chastised the Marketing and Sales director for not having an established procedure for selecting distributors. This resulted in a detailed questionnaire being developed for assessing potential distributors. The questionnaire was first to be tested on 10 to 15 large, long-standing Vinchel partners. After that, the final version would allow for the build-up of Vinchel's distributor networks.

\section{Pricing Strategies}

Vinchel's marketing department developed wholesale and retail prices for two groups of products, "Vinchel Elite" and "Vinchel Standard". The most prestigious and, correspondingly, the most expensive brands, eight in number, were included in the "Vinchel Elite" category; the rest of the company's products, 12-18, were placed in the "Vinchel Standard" group. Taking into account transportation costs and markups, a 0.7 liter bottle of "Vinchel Elite" was wholesaled at 45-55 rubles and retailed at 70-90 rubles. "Vinchel Standard" wines carried a wholesale price of $30-35$ rubles and a retail price of 50 to 65 rubles.

\section{Competition}

Vinchel had to compete with both foreign and domestic wine companies. Foreign wine companies generally operate in Russia through distributors. The Director General had a list of these major distributors. These were:

- $\quad$ Agroprodintorg, Ltd. (Russian Federation), an import company, is a leading supplier of Moldovan wines.

- $\quad$ Alfa Spirits Group (Russian Federation) is an exclusive distributor for leading western companies. 
- $\quad$ Angel, Ltd. (Moldova) is a producer and vendor of a wide assortment of Moldovan wines.

- $\quad$ Vifran, Ltd. (Russian Federation) is a supplier of French wines.

- $\quad$ Vinikom is a leading supplier of Spanish wines.

- $\quad$ The Mosel Company is a wholesale trading company that sells wine produced in Western Europe.

- $\quad$ Rigal (Russian Federation) is a major supplier of Moldovan wines.

- $\quad$ Scorpio and Co. (Russian Federation) is a distributor of Spanish wines.

- $\quad$ The Garling trading house (Russian Federation) is a representative for Moldovan wine producers.

- Vinorum is a major distributor of Moldovan wines, shipping 17 million barrels in 1999. It received \$30 million from the European Bank for Reconstruction and Development to develop Moldova's wine industry in a joint venture with Moldova's Bardar and Khynchet wineries which are owned by Vinorum.

- $\quad$ Legenda Kryma, Moscow, is the exclusive distributor for Crimean wines.

- Massandra and Novy Svet. Most of the distributor's 10 million liters of elite wines sold in the last five years were targeted for Moscow through 200 retail outlets, but expansion into the other areas of Russia was likely.

- Dionis, a Georgian company which produces wine in Georgia and Moldova and sells them in Russia through distributors, has opened a new $\$ 2$ million winery in Tbilsi. The company sells 200,000 bottles of Georgian wines in Russia per month, half of the total output of Georgian wines. The new winery is expected to increase that share to $75 \%-80 \%$. Russia is the leading market for Georgian wines.

Domestic wine makers also were scrutinized carefully by Mr. Bondarev. Wine companies in Nizhny Novgorod had planned to increase production of wine and low alcohol drinks from 500,000 liters in the first half of 2000 to 3.1 million liters in the second half. Nizhny Novgorod Sparkling Wines was planning to upgrade its production to 500,000 liters from Moldovan and Krasnodap sources. Sarmov Experimental Wine- Making Plants, which depends on materials from Italy, Spain and Drasnodar, intended to upgrade its bottling line so that it could produce 700,000 liters. Vinagroprom obtained equipment so it could bottle Spanish wines and increase its capacity to 500,000 liters. Likon is investing 20 million rubles to produce wine and cognac products. Its total capacity was estimated at 300,000 liters. Rossi expected to produce 500,000 liters of low alcohol drinks and 200,000 liters of drink mixes were expected to be produced by Bykov and Company.

Moscow Champagne Winery, the Russian capital's largest alcoholic beverage producer, was going to increase its capacity by $67 \%$ in 1999 over 1998 's, reaching an output of 20 million bottles of champagne wines. The company has a number of white and sparkling wines, and a natural sparkling wine, as well as the very popular Rossiikoye Shampanskoye brand, which it sells throughout Russia and exports to Greece, Germany and Vietnam. The winery is employee-owned and was incorporated in 1995--fifteen years after its founding.

In 1998, Volgograd Winery produced 3.8 million liters. Output was to be increased to 5 million liters in 1999. Turnover in 1999 was 120 million rubles, up from 73.8 million in 1998. Launched in 1962, this state unitary company markets 25 brandname products and has 240 employees.

After four years in bankruptcy, the Samtrest-Sainkt-Petersburg Winery (St. Petersburg) was restarted under new ownership. Fuad Nasir-Zode, General Director, stated that the company would be producing 500,000 bottles of wine per month by the end of 1999 and up to one million bottles per month by the summer of 2000. Close to a million dollars had been put into upgrades, mainly for the installation of five German and Italian bottling lines. Wine materials would be brought in from Georgia, Azerbaijan and Moldova. Four-fifths of its Soviet-era specialists have been retained. Within the next several years, the company planned to produce three new varieties to be added to the four already existing: Marli, Mtskheti, Marani, and Marneuli. Eighty percent of its sales are in St. Petersburg and the Leningrad region; the balance is northwest and central Russia.

Dacia Fenix Winery, located in Ufa, is owned by the Moldovan Department for Privatization and Management of State Property. The Department announced in 1999 a tender offer for the company.

One of the capital city's largest producers of wine, Moscow Wines and Cognac, planned to increase its output. According to Vladimir Martynov, its general director, the company currently produces 80,000 liters of 
Monastyrskaya rapeza and 40,000 liters of Kvpava wines. About half of its sales are in Moscow and its environs, the rest in other areas of Russia.

\section{REFERENCES}

1. Pierre Spahni, International Wine Trade, Woodhead Publishing Limited, Cambridge, England, 1998, pp. 36-37.

2. Lawrence M. Fisher, How Mondavi is Growing Around the World, Strategy \& Business, Second Quarter 1999, pp. 76-84.

3. Stuart Pinkerton, It's a Drink, Not an Investment, Forbes, August 25, 1997, pp. 278-279.

4. Christie's to Auction Blockbuster Wine Collection, Wine Spectator, June 15, 1994, p.18.

5. Pierre Spahni, p. 45.

6. Pierre Spahni, p. 46.

7. Russia's Road to Corruption, Speaker's Advisory Group on Russia, U.S. House of Representatives, Washington, D.C., September 2000.

8. Russia's Road to Corruption.

9. Boom and Gloom, The Economist, November 25, 2000, p. 97.

10. Paul Starobin and Olga Kravchenko, Russia's Middle Class, Business Week, October 16, 2000, pp. 78-85.

11. The World in 2001, The Economist, 2001, p. 86.

12. Pierre Spahni, pp. 277-279.

13. European Marketing Data and Statistics 2000, Euromonitor, London.

\section{EXHIBIT 1 \\ THE WINEMAKING PROCESS}

\begin{tabular}{|c|}
\hline STEMIIING/CRUSHING \\
\hline PRESSING (WHITE AND ROSÉS) \\
\hline FERMENTATION \\
\hline PRESSING (REDS) \\
\hline STABILIZATION/CLARIFICATIO. \\
\hline BLENDING \\
\hline \begin{tabular}{l|} 
EVENTUAL AGING IN CASKS \\
\end{tabular} \\
\hline BOTTLING/DISPATCHING \\
\hline
\end{tabular}

Source: Pierre Spahni, The International Wine Trade, Woodhead Publishing Limited, Cambridge, England, 1998, p. 16. 
EXHIBIT 2

VINCHEL PRODUCTS AWARDED MEDALS AT INTERNATIONAL EXHIBITIONS IN 1998-1999

\begin{tabular}{|c|c|}
\hline Tsarsky Pogrebok (Tsar's Cellar) & 2 gold, 1 bronze \\
\hline K Svadbe (For the Wedding) & 1 gold, 2 bronze \\
\hline Nezhnost (Tenderness) & 1 gold, 2 bronze \\
\hline Aromat Lubvi (Love Fragrance) & 1 gold, 2 silver \\
\hline Dlya Vas (For You) & 1 gold, 2 silver, 2 bronze \\
\hline Staraya Taverna (Old Tavern) & 1 gold, 1 silver, 3 bronze \\
\hline Naslazhdeniye (Pleasure) & 1 gold, 1 silver \\
\hline U Kamina (By the Fireplace) & 1 gold, 1 silver \\
\hline Port-wine Soblazn (Temptation) & 1 gold, 1 silver \\
\hline Port-wine Uspekh (Success) & 1 gold \\
\hline Skazka (Fairy-tale) & 1 gold, 1 silver \\
\hline Vostorg (Delight) & 2 silver, 2 bronze \\
\hline Arabella & 1 silver, 2 bronze \\
\hline Port-wine 98 & 1 silver, 2 bronze \\
\hline Uralskie Samotsvety (The Urals Semi-Precious Stones) & 2 bronze \\
\hline Ogni Urala (The Urals Lights) & \\
\hline
\end{tabular}

EXHIBIT 3

BALANCE SHEET

VINCHEL JOINT STOCK COMPANY

AS OF SEPTEMBER 30, 2000

\section{ASSETS \\ Liquid Assets}

Cash

Accounts Receivable

Inventories (Commodity)

Inventories (Raw Materials)

Total Current Assets

Non-Liquid Assets

Gross Plant and Equipment

Transportation

Depreciation

Total Non-liquid Assets

Total Assets

\section{LIABILITIES AND EQUITY}

\section{Liabilities}

Accounts Payable

Current Payments on Long-term

Debt (3)

Long-term Debt

Total Liabilities

Equity

Undistributed Profit

Total Liabilities and Equity

\section{RUBLES}

3.3 million

9.7 million

3.0 million

$\underline{14.4 \text { million }}$

30.4 million

14.2 million

3.5 million

2.9 million

20.6 million

51.0 million

4.7 million

2.5 million

$\underline{10.4 \text { million }}$

17.6 million

32.4 million

1.0 million

$\overline{51.0 \text { million }}$ 


\section{EXHIBIT 4}

\section{DATA ON 76 REGIONS TO BE USED IN VINCHEL'S EXPANSION PROGRAM IN RUSSIA}

\begin{tabular}{|c|c|c|c|c|}
\hline & NAME OF THE REGION & $\begin{array}{l}\text { Population } \\
\text { (Millions) }\end{array}$ & $\begin{array}{l}\text { Consumer Index of } \\
\text { the Region }\end{array}$ & $\begin{array}{c}\text { Distance from } \\
\text { Chelyabinsk to } \\
\text { Large Cities } \\
\text { (Kilometers) }\end{array}$ \\
\hline 1. & Moscow and Moscow oblast (region) & 15,343 & 0,206 & 1901 \\
\hline 2. & St. Petersburg and Leningrad oblast & 6,512 & 0,050 & 2585 \\
\hline 3. & Sverdlovsk oblast & 4,703 & 0,320 & 230 \\
\hline 4. & Tumen oblast & 3,157 & 0,028 & \\
\hline 5. & Krasnodarsk oblast & 5,004 & 0,026 & 2746 \\
\hline 6. & Kemerovo oblast & 3,078 & 0,025 & \\
\hline 7. & Nizhny Novgorod oblast & 3,741 & 0,022 & 1632 \\
\hline 8. & Samara oblast & 3,305 & 0,022 & 852 \\
\hline 9. & Republic Tartarstan & 3,755 & 0,022 & 2050 \\
\hline 10. & Chelyabinsk oblast & 3,700 & 0,021 & \\
\hline 11. & Republic Bashkortostan & 4,080 & 0,021 & \\
\hline 12. & Krasnoyarsk krai & 3,117 & 0,021 & \\
\hline 13. & Irkutsk oblast & 2,805 & 0,020 & \\
\hline 14. & Perm oblast & 3,024 & 0,019 & \\
\hline 15. & Rostov oblast & 4,429 & 0,019 & 2470 \\
\hline 16. & Primorsky krai & 2,273 & 0,017 & \\
\hline 17. & Novosibirsk oblast & 2,748 & 0,016 & \\
\hline 18. & Volgorgad oblast & 2,695 & 0,014 & 2129 \\
\hline 19. & Altaisky krai & 2,697 & 0,014 & \\
\hline 20. & Saratov oblast & 2,739 & 0,014 & \\
\hline 21. & Omsk oblast & 2,180 & 0,013 & \\
\hline 22. & Stavropolsky krai & 2,650 & 0,013 & \\
\hline 23. & Voronezh oblast & 2,507 & 0,012 & 1862 \\
\hline 24. & Khabarovsky krai & 1,588 & 0,011 & \\
\hline 25. & Tula oblast & 1,826 & 0,011 & 1915 \\
\hline 26. & Republic Sakha (Yakutiya) & 1,036 & 0,011 & \\
\hline 27. & Arkhangelsk oblast & 1,535 & 0,010 & \\
\hline 28. & Kirovsk oblast & 1,645 & 0,010 & \\
\hline 29. & Yaroslavl oblast & 1,456 & 0,010 & \\
\hline 30. & Republic Udmurtiya & 1,641 & 0,010 & \\
\hline 31. & Orenburg oblast & 2,223 & 0,010 & \\
\hline 32. & Tver oblast & 1,653 & 0.009 & 2050 \\
\hline 33. & Vologda oblast & 1,354 & 0,009 & 2129 \\
\hline 34. & Ulyanovsk oblast & 1,492 & 0,009 & 1162 \\
\hline 35. & Vladimir oblast & 1,648 & 0,009 & 1867 \\
\hline 36. & Republic Komi & 1,202 & 0,008 & \\
\hline 37. & Murmansk oblast & 1,067 & 0,008 & \\
\hline 38. & Chita oblast & 1,299 & 0,008 & \\
\hline 39. & Belgorod oblast & 1,458 & 0,008 & 2125 \\
\hline 40. & Bryansk oblast & 1,480 & 0,008 & \\
\hline 41. & Amur oblast & 1,041 & 0,008 & 1258 \\
\hline 42. & Penza oblast & 1,566 & 0,007 & 1282 \\
\hline 43. & Republic Karelia & 789 & 0,007 & \\
\hline 44. & Republic Buryatiya & 1,053 & 0,007 & \\
\hline 45. & Republic Chuvashiya & 1,361 & 0,007 & \\
\hline 46. & Kaluga oblast & 1,094 & 0,007 & 2017 \\
\hline 47. & Ryazan oblast & 1,332 & 0,007 & 1726 \\
\hline 48. & Kursk oblast & 1,349 & 0,007 & 2199 \\
\hline
\end{tabular}




\begin{tabular}{|c|c|c|c|c|}
\hline & NAME OF THE REGION & $\begin{array}{l}\text { Population } \\
\text { (Millions) }\end{array}$ & $\begin{array}{l}\text { Consumer Index of } \\
\text { the Region }\end{array}$ & $\begin{array}{l}\text { Distance from } \\
\text { Chelyabinsk to } \\
\text { Large Cities } \\
\text { (Kilometers) }\end{array}$ \\
\hline 49. & Tambov oblast & 1,315 & 0,007 & 1595 \\
\hline 50. & Smolensk oblast & 1,173 & 0,007 & 2293 \\
\hline 51. & Lipetsk oblast & 1,250 & 0,007 & 1736 \\
\hline 52. & Kaliningrad oblast & 926 & 0,006 & \\
\hline 53. & Sakhalin oblast & 673 & 0,006 & \\
\hline 54. & Tomsk oblast & 1,079 & 0,006 & \\
\hline 55. & Ivanovo oblast & 1,275 & 0,006 & 1970 \\
\hline 56. & Republic Dagestan & 2,067 & 0,006 & \\
\hline 57. & Oryol oblast & 916 & 0,006 & 2039 \\
\hline 58. & Kurgan oblast & 1,117 & 0,006 & \\
\hline 59. & Novgorod oblast & 746 & 0,005 & 2405 \\
\hline 60. & Kostroma oblast & 809 & 0,005 & 2065 \\
\hline 61. & Astrakhan oblast & 1,024 & 0,005 & \\
\hline 62. & Kamtchatka oblast & 423 & 0,005 & \\
\hline 63. & Pskov oblast & 835 & 0,005 & \\
\hline 64. & Republic Mordoviya & 959 & 0,004 & \\
\hline 65. & Republic Mariy-El & 766 & 0,004 & \\
\hline 66. & Republic Khakasiya & 584 & 0,004 & \\
\hline 67. & Republic Kabardino-Balkariya & 790 & 0,003 & \\
\hline 68. & Magadan oblast & 279 & 0,003 & \\
\hline 69. & Republic Severnaya Osetiya & 659 & 0,002 & \\
\hline 70. & Republic Adygeya & 451 & 0,002 & \\
\hline 71. & Republic Karachaevo-Tcherkessiya & 436 & 0,002 & \\
\hline 72. & Yevreiskaya autonomous oblast & 212 & 0,001 & \\
\hline 73. & Republic Tuva & 308 & 0,001 & \\
\hline 74. & Republic Kalmykiya & 320 & 0,001 & \\
\hline 75. & Republic Gornyi Altai & 200 & 0,001 & \\
\hline 76. & Tchukotka autonomous okrug & 100 & 0,001 & \\
\hline
\end{tabular}


EXHIBIT 5

MAP OF RUSSIA

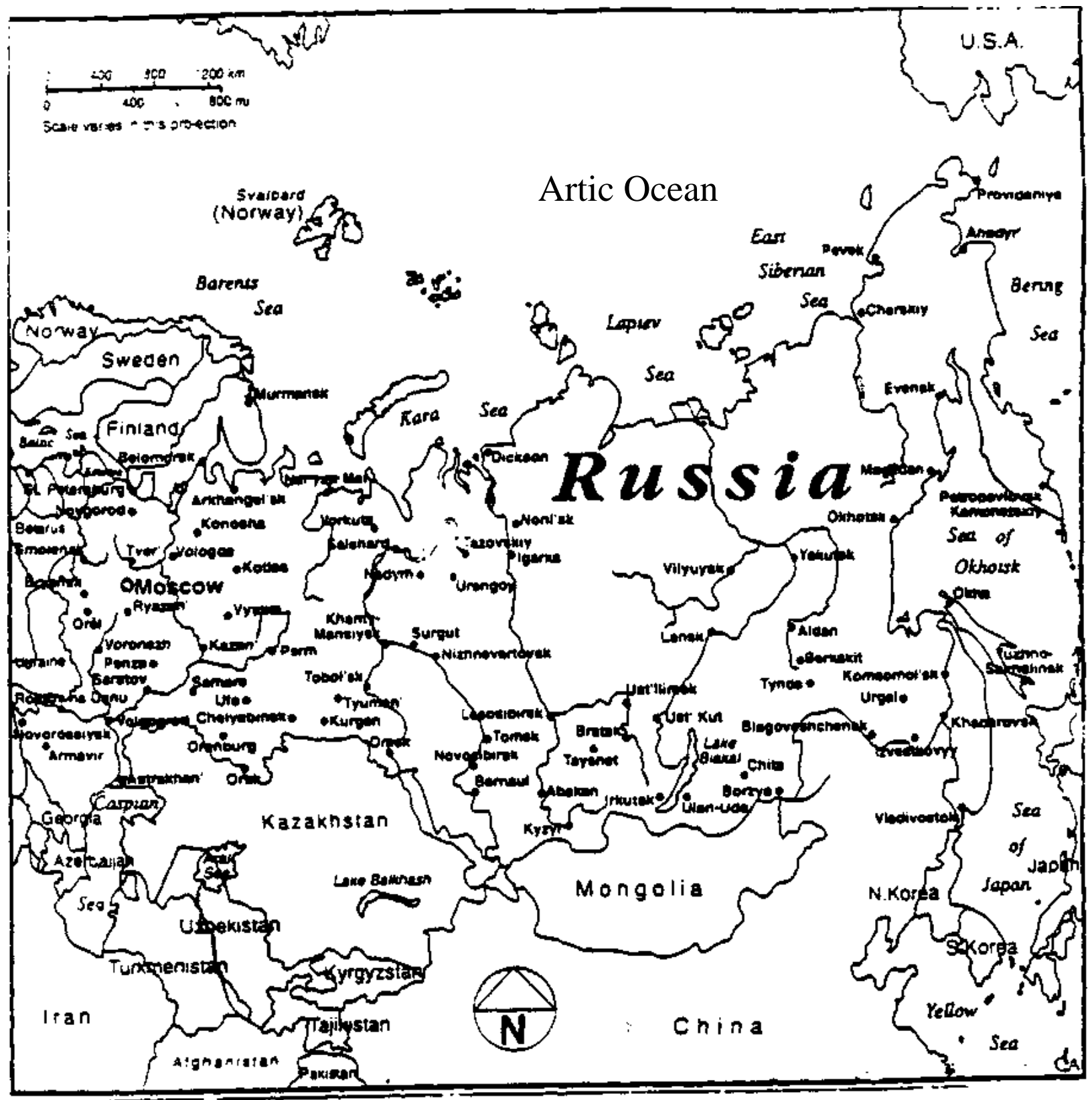

